\title{
ANALYSIS OF THE COMPLIANCE OF THE MEDICAL WASTE MANAGEMENT PROCESS IN THE COUNTRIES OF THE WESTERN BALKANS AND THE EU
}

\author{
UDC 628.4.046:628.477
}

\author{
Nenad Živković ${ }^{1}$, Rade Milošević ${ }^{2}$ Žarko Vranjanac ${ }^{1}$, \\ Dejan Vasović ${ }^{1}$, Snežana Stević ${ }^{3}$ \\ ${ }^{1}$ University of Niš, Faculty of Occupational Safety in Niš, Serbia \\ ${ }^{2 "}$ Union - Nikola Tesla" University, Faculty of Construction Management, Belgrade, Serbia \\ ${ }^{3}$ University of Priština, Faculty of Medicine, Kosovska Mitrovica, Kosovo/Serbia
}

\begin{abstract}
From a global perspective, the negative consequences of the medical waste impact on human health and the environment are becoming increasingly intensified nowadays. On the one hand, these consequences are manifested as infections, injuries and diseases, while on the other hand they cause soil, water and air contamination with pollutants from medical waste. The aim of this paper is to define the principles of a medical waste management programme within medical institutions. By analysing the previous research on medical waste, the paper gives a systematic presentation of the definition, classification and labelling of medical waste, as well as the ecotoxicological risk to the environment and health, thus creating a basis for reviewing the strategies of the management programme for this type of waste. Based on the analysis of the available data on generated medical waste in a given territory, the measures of adequate medical waste management can be applied with the aim of eliminating or minimizing negative consequences of this waste on human health and the environment. A comparative qualitative analysis of medical waste was conducted in the paper. In addition, applying the analysis of potential methods of medical waste treatments indicated the importance of selecting strategies for medical waste management, which was observed from several perspectives. The defined principles for the implementation of a medical waste management programme represent the key result of this study. The paper provides an overview of the tools for drafting the waste management plan, as well as an example of a diagram intended to support the decision-making on the treatment methods to be used in the absence of appropriate regional infrastructures.
\end{abstract}

Key words: medical waste, classification and categorization, management process

Received November 3, 2018 / Accepted November 8, 2018

Corresponding author: Žarko Vranjanac

University of Niš, Faculty of Occupational Safety in Niš, Čarnojevića 10a, 18000 Niš, Serbia

E-mail: zarko.vranjanac@znrfak.ni.ac.rs 


\section{INTRODUCTION}

In recent decades, medical waste has been recognized as a current problem of modern society. In the Republic of Serbia, this waste has been generated by medical institutions such as clinical centres, the Military Medical Academy, hospitals, military hospitals, health centres, military medical centres and clinics.

There is no legislative, terminological and conceptual unity of medical waste and its classification in literature. Namely, there are differences from one country to another regarding these issues, as shown by the examples from the United States, the European Union (EU) and developing countries, with a focus on the analysis of Western Balkan countries: Serbia, Croatia, Bosnia and Herzegovina, and Montenegro.

Medical waste is highly regulated in the United States, with the main piece of legislation governing American medical waste being the Medical Waste Tracking Act (MWTA) of 1988. The MWTA has served as the basis for medical waste classification, handling, transportation, treatment and disposal in the United States ever since. In addition to governing the collection and transport of medical waste, the MWTA also required the Environmental Protection Agency (EPA) to examine various treatment technologies available at the time for their ability to reduce the disease-causing potential of medical waste. The technologies that EPA examined in 1990 included incinerators, autoclaves, microwave units and various chemical and mechanical systems. In the European Union (EU), the European Commission (EC) sets directives for waste regulations and standards, and then member nations are responsible for enacting legislations that comply with and serve to fulfil these EC directives. As such, the EC has directed countries in the European Union to classify their waste according to Chapter 18 of the European Waste Catalogue (EWC), in which the EC has established a list of waste descriptions for different components of medical waste. Since 1994, the Directory on Hazardous Waste has regulated hazardous waste in the EU, defining and governing 237 types of hazardous waste, including medical waste. In 2000, the European Union enacted stricter emission limits for medical incineration facilities. This has caused a trend towards the shutdown of waste incineration facilities in favour of non-incineration methods of treatment, such as autoclave sterilization. Even when a developing country enacts a medical waste legislation, there is often a marked discrepancy between the thoroughness of the legislation and the reality of medical waste management in that country [1].

Until recently, inadequate medical waste management represented a significant problem in the Republic of Serbia because waste in health facilities was not separated and it was disposed in landfills where it was mixed with municipal waste. In 2007, the Ministry of Health started specific activities with the aim of introducing a uniform medical waste management system, especially regarding the category of infectious medical waste. In 72 health centres in the Republic of Serbia, 78 autoclaves and crusher for the sterilization of medical waste were installed, 25 vehicles for the transport of medical waste were purchased and medical workers were trained to classify waste in health facilities [2]. The National Guide to Medical Waste Management has been prepared and its aim is to offer a comprehensive and unique approach to safe medical waste management in both public and private health institutions, as well as in social care institutions throughout the Republic of Serbia. To date, a legislative framework for the field of medical waste has been established in the Republic of Serbia, consisting of the following most important regulations: Law on Waste Management, Law on Environmental Protection, Law on the Confirmation of the 
Basel Convention on the Control of Transboundary Movements of Hazardous Wastes and their Disposal and Ordinance on Medical Waste Management [3,4,5,6].

According to the adopted waste management strategy for period 2010-2019, it is the responsibility of Serbian health institutions to implement the practice of responsible and orderly medical waste management, with the possession and development of an institution's waste management plan, as a key document defining activities in this field. All health institutions that produce medical waste are required to develop waste management plans (if they generate more than $100 \mathrm{~kg}$ of hazardous waste per year) and appoint an entity responsible for waste management. The Medical Waste Management Team realizes the synchronization of medical waste management activities in health institutions. In Bosnia and Herzegovina, the Waste Management Plan 2012 - 2017 was adopted, and most cantons have their own waste management strategies and regulations, including medical waste [7]. The Republic of Srpska adopted the Draft Waste Management Strategy in the Republic of Srpska 2017 - 2025, which lists the biggest weaknesses regarding medical waste management. In the past ten years, in Montenegro there were improvements of the legislation related to the disposal of waste from health institutions, which explicitly prescribed the manner in which waste is to be collected, sorted and disposed of. Yet, most institutions did not apply the regulations. To overcome the medical institutions problems regarding medical waste in Montenegro, the Medical Waste Management Plan was adopted. The document is designed to present a detailed analysis of the current state of medical waste in health institutions, followed by the measures and activities planned in order to overcome the problems regarding medical waste management. The aim of this document is to establish good practice in managing medical waste, which would represent the basis of regulating the functioning of health institutions and which would cover all administrative levels $[8,9]$.

\section{Classification AND CATEgorization OF Medical Waste}

Medical waste is defined by the World Health Organization (WHO) as: "waste that is generated in the diagnosis, treatment or immunization of human beings or animals". A significantly more comprehensive definition is provided in the legislative framework of the Republic of Serbia, where medical waste is defined as waste arising from facilities where health care is provided to people or animals and/or from other places where health service is provided (from diagnostics, experimental work, laboratory, cleaning, maintenance, and space and equipment disinfection), and it includes non-hazardous and hazardous medical waste. Non-hazardous medical waste is not contaminated with dangerous or other substances, and its composition is similar to municipal waste composition (recyclable, biodegradable, etc.). Hazardous medical waste requires special treatment, i.e. it is waste which has one or more hazardous characteristics that make it hazardous waste, such as: pathoanatomical waste, sharp objects, pharmaceutical waste, including cytotoxic and cytostatic waste, waste contaminated with blood and bodily fluids, infectious and other hazardous medical waste (chemical waste, heavy metal waste and pressurized bottles).

The classification of medical waste can be done based on various criteria, such as: degree of hazard (non-hazardous and hazardous), origin (clinical and non-clinical), place of origin (larger and smaller source), consistency (solid, liquid and gas), etc. The present paper includes an overview of two internationally recognized classifications of medical waste, according to the WHO and the European Waste Catalog, shown in Figure 1. 


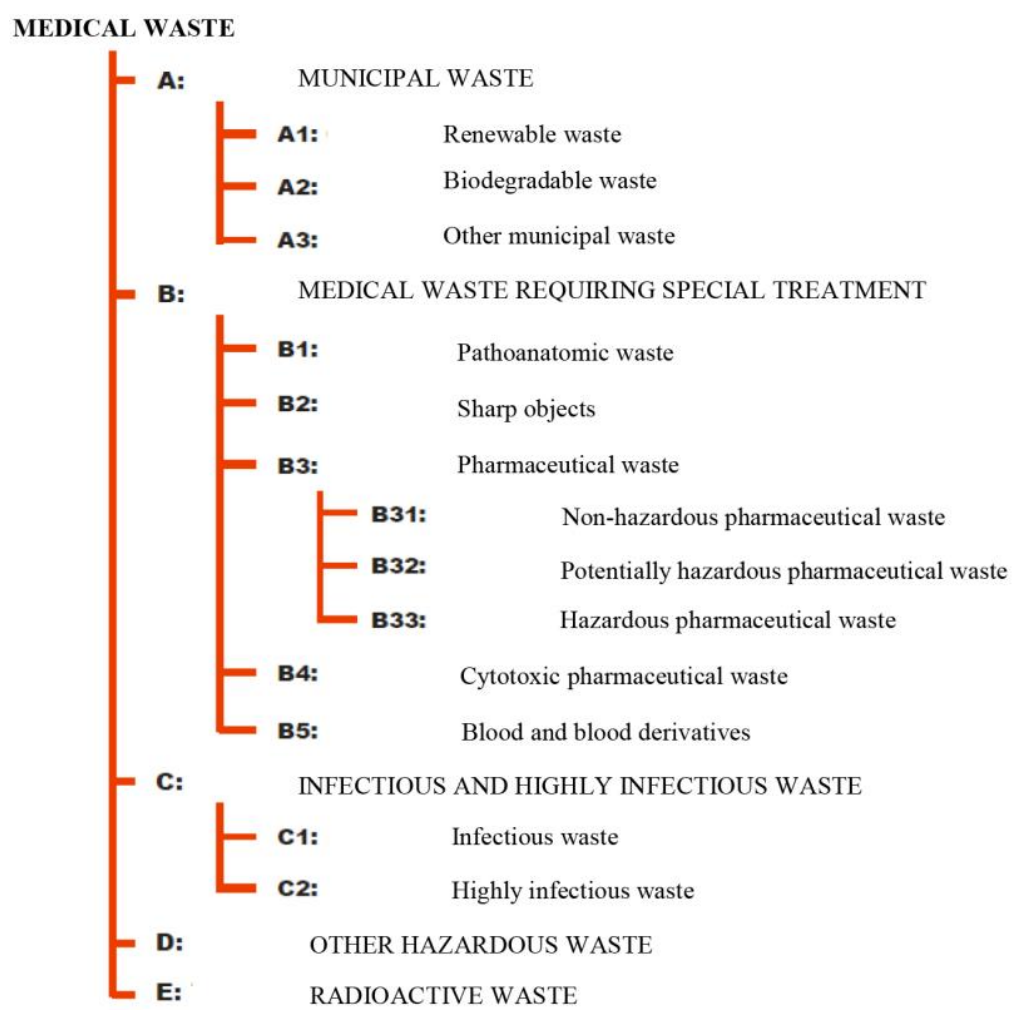

Fig. 1 The standard classification of medical waste according to the European Waste Catalog

The Catalog illustrated in Table 1 has been in use in all countries of the Western Balkan, including the Republic of Serbia, since 2005 [10].

Table 1 The classification of medical waste according to the European Waste Catalog

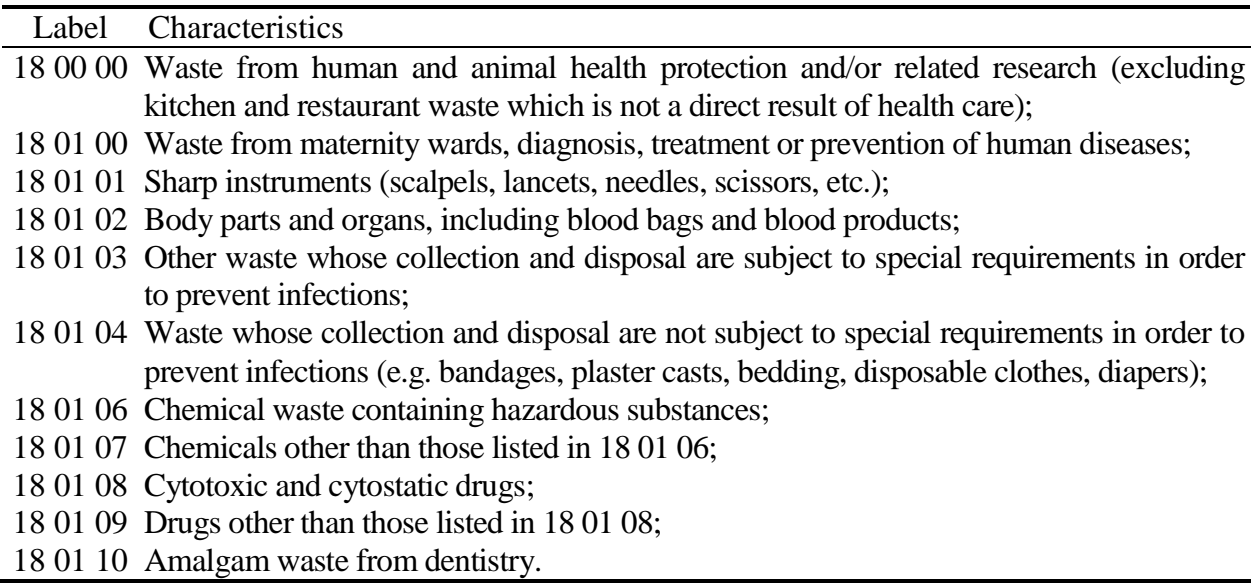


The classification of hazardous medical waste according to the WHO diverse range of materials is illustrated in Table 2 [11].

Table 2 The classification of medical waste according to the WHO

\begin{tabular}{|c|c|c|}
\hline $\begin{array}{c}\text { Waste } \\
\text { category }\end{array}$ & Waste type & Characteristics \\
\hline 1 & Infectious & $\begin{array}{l}\text { Waste contaminated with blood and other bodily fluids (e.g. from } \\
\text { discarded diagnostic samples), cultures and stocks of infectious } \\
\text { agents from laboratory work (e.g. waste from autopsies and } \\
\text { infected animals from laboratories), or waste from patients in } \\
\text { isolation wards and equipment (e.g. swabs, bandages and } \\
\text { disposable medical devices); }\end{array}$ \\
\hline 2 & $\begin{array}{l}\text { Pathological } \\
\text { waste }\end{array}$ & $\begin{array}{l}\text { Human tissues, organs or fluids, body parts and contaminated } \\
\text { animal carcasses; }\end{array}$ \\
\hline 3 & Sharps & Syringes, needles, disposable scalpels and blades, etc.; \\
\hline 4 & Chemicals & $\begin{array}{l}\text { Solvents used for laboratory preparations, disinfectants and } \\
\text { heavy metals contained in medical devices (e.g. mercury in } \\
\text { broken thermometers) and batteries; }\end{array}$ \\
\hline 5 & Pharmaceuticals & Expired, unused and contaminated drugs and vaccines; \\
\hline 6 & Genotoxic waste & $\begin{array}{l}\text { Highly hazardous, mutagenic, teratogenic or carcinogenic, such } \\
\text { as cytotoxic drugs used in cancer treatment and their metabolites; }\end{array}$ \\
\hline 7 & $\begin{array}{l}\text { Radioactive } \\
\text { waste }\end{array}$ & $\begin{array}{l}\text { Products contaminated by radionuclides, including radioactive } \\
\text { diagnostic material or radiotherapeutic material; }\end{array}$ \\
\hline 8 & $\begin{array}{l}\text { Non-hazardous } \\
\text { general waste }\end{array}$ & $\begin{array}{l}\text { Waste that does not pose any particular biological, chemical, } \\
\text { radioactive or physical hazard. }\end{array}$ \\
\hline
\end{tabular}

The structure of waste generated in health institutions, based on WHO statistics, is illustrated in Figure 2.

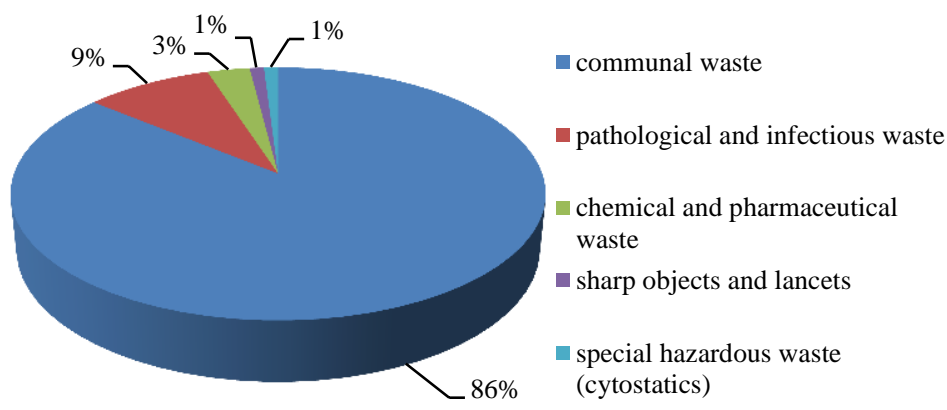

Fig. 2 The structure of waste generated in health institutions

According to the data of the medical waste management department at the Institute of Public Health of Serbia Dr Milan Jovanovic Batut, the most frequent flow of hazardous medical waste is infectious waste ( $15 \%$ to $25 \%$ of the total waste from health care), followed by sharp objects waste $(1 \%)$, pathoanatomic waste $(1 \%)$, chemical or pharmaceutical 
waste (3\%), and radioactive and cytotoxic waste, as well as waste containing mercury (less than $1 \%$ ) [12].

All people who are in contact with hazardous medical waste are potentially exposed to the various risks it entails: persons inside the establishment generating the waste, those who handle it, and persons outside the facility who may be in contact with hazardous wastes or their by-products, if there is no medical waste management or if that management is inadequate.

The following groups of people are potentially exposed:

- Inside the hospital: care staff (doctors, nursing staff, auxiliaries), stretcher-bearers, scientific, technical and logistic personnel (cleaners, laundry staff, waste managers, carriers, maintenance personnel, pharmacists, laboratory technicians, patients, families and visitors).

- Outside the hospital: off-site transport personnel, personnel employed in processing or disposal infrastructures, the general population (including adults or children who salvage objects found around the hospital or in open dumps).

Health risks associated with hazardous medical waste can be divided into five categories:

- risk of trauma (waste category 1 );

- risk of infection (waste categories 1 and 2);

- chemical risk (waste categories 3,4, 5 and 6);

- risk of fire or explosion (waste categories 3,4,5 and 6);

- risk of radioactivity (waste category 7, which is not dealt with in this paper).

Health and environmental risks caused by hazardous agents from medical waste best illustrate the degree of hazard of this waste, taking into account that about $15 \%$ of medical waste is hazardous, while the remaining $85 \%$ is non-hazardous waste. Apart from general health-care waste, which may be dealt with by a normal domestic and urban waste management system, medical waste also includes pathological and infectious waste, sharps waste, chemical or pharmaceutical waste and special waste, such as radioactive or cytostatic waste, pressurized containers, or broken thermometers and used batteries. Medical waste contains potentially harmful chemicals and microorganisms which can infect hospital patients, health workers and the general public. Other potential infectious risks may include the spread of drug-resistant microorganisms from health facilities into the environment. Medical waste management process can be divided into four sub-processes: diagnosis and therapy, transport (both internal and external) and waste treatment [13,14]. Infection spreading can be caused by infections at any of these four stages of infectious medical waste management. Health risks also include radiation burns, sharps-inflicted injuries, poisoning and pollution through the release of pharmaceutical products, in particular, antibiotics and cytotoxic drugs, and through waste water by toxic elements or compounds such as mercury or dioxins that are released during incineration of medical waste $[15,16]$.

According to the information that was published in 2004 in the WHO report about the impact of chemicals on health, 5 million people a year lose their lives due to certain chemical exposure in the environment. The report warns that these figures are much higher because the chemicals are being used more and more, but there is a lack of research of their combined (cumulative) effect on the human body [17]. According to this report, 5 million people die in the world because of exposure to chemicals, which is $8.3 \%$ of the total number of deaths, and 86 million years of life are lost due to diseases and disabilities caused by exposure to certain chemicals in the environment on an annual basis. By comparison, the number of years of life that the world population loses for this 
reason is considerably larger than the number of years that are lost due to malignant diseases (75 million years) [18]. Bearing in mind that this information is provided in the report for 2004, the World Health Organization warns that the situation is even more dramatic, since the quantities of chemicals with negative effects are increasing steadily.

With respect to the abovementioned WHO report, it is of paramount importance that an estimated 16 billion injections are administered every year worldwide. Not all needles and syringes are disposed of safely, creating the risk of injuries and infection, and opportunities for reuse. In 2010, unsafe injections were still responsible for as many as 33800 new HIV infections, 1.7 million hepatitis B infections (HBV) and 315000 hepatitis C infections (HBC). A person who experiences a needle stick injury from a needle used on an infected source patient has the risk of becoming infected with HBV (30\%), HCV (1.8\%) and HIV $(0.3 \%)$

The quantities of generated medical waste, depending on: the national income, the source size (in highly developed countries) and the type of medical waste, are shown in Tables 3,4,5, respectively [19].

Table 3 Generation of medical waste according to the national income

\begin{tabular}{lc}
\hline National income level & Annual waste generation $(\mathrm{kg} / \mathrm{head}$ of population) \\
\hline High-income countries & $1.1-12.0$ \\
Middle-income countries & $0.8-0.6$ \\
Low-income countries & $0.5-3.0$ \\
\hline
\end{tabular}

Table 4 Generation of medical waste depending on the source size in highly developed countries

\begin{tabular}{lc}
\hline Source of waste generation & Daily waste generation $(\mathrm{kg} / \mathrm{bed})$ \\
\hline University clinics & $4.1-8.7$ \\
General hospitals & $2.4-4.2$ \\
Regional hospitals & $0.5-1.8$ \\
Health centres & $0.05-0.2$ \\
\hline
\end{tabular}

Table 5 Generation of medical waste, depending on the type of medical waste (hospitals in Western Europe)

\begin{tabular}{lc}
\hline Waste type & Daily waste generation $(\mathrm{kg} / \mathrm{bed})$ \\
\hline Chemical and pharmaceutical waste & 0.5 \\
Sharps & 0.04 \\
Combustible packaging & 0.5 \\
\hline
\end{tabular}

According to the WHO, highly developed industrial countries annually produce up to $6 \mathrm{~kg}$ of hazardous medical waste per capita. Based on the presented data it can be concluded that health-care waste generation is usually lower in low- and middle- income countries (including Serbia) than in high-income countries. On the other hand, with regard to the source size, in highly developed countries, the largest amount of medical waste is generated by the University and General Hospital. Regarding the type of medical waste generated in Western European hospitals, the largest amount of generated waste belongs to the group of chemical and pharmaceutical waste and combustive packaging. 
Based on the data presented in several studies, it has been established that the population of Serbia (about 7.3 million people) annually generates between 4500 and 5000 tons of infectious waste from health care, of which $1 / 5$ originates from outpatient health care, $2 / 3$ from hospital care, while about $5 \%$ is generated by microbiological medical laboratories. In 2009, only 1/3 of this type of waste was treated before disposal [20].

Waste generation in health institutions in the Republic of Croatia is uneven. The amount and type of waste depends mostly on the size and type of the health institution. The total hazardous medical waste ranges from 0.5 to $3 \mathrm{~kg}$ per inhabitant per year [21].

Bosnia and Herzegovina and the Republic of Srpska annually generate 930 tons of medical waste. There is no data on the export of medical waste from Bosnia and Herzegovina, nor is there any precise data on the number of medical waste sources. The regulations stipulate that certain types of this waste must be burned in the European Union countries, since there are no incineration plants available for pharmaceutical and chemical waste in Bosnia and Herzegovina. As a result, medical waste hazardous to human health and the environment ends up in ordinary landfills. It is estimated that around $2.16 \mathrm{~kg}$ of waste per year is produced in health institutions in the Republic of Srpska and $2.2 \mathrm{~kg}$ in Bosnia and Herzegovina. Part of that waste is hazardous to human health and the environment (around 15\%). However, there is no precise data on the total amount of medical waste, including hazardous waste, but only estimates based on the number of hospital beds. According to these estimates, about 430 tons of hazardous waste is produced annually in health institutions in the Republic of Srpska, and about 500 tons in the Bosnia and Herzegovina. Sveti Apostol Luka Hospital in Doboj owns its own facility for infectious medical waste treatment. Medical waste is separated on site in the two largest health institutions - University Clinical Center of the Republic of Srpska (UCC RS) and Clinical Center University of Sarajevo (CCUS) [22].

In health institutions in Montenegro waste sorting is conveyed at the place of its origin and it is transported to a temporary warehouse, which is located within the institution. The exceptions are General Hospital Berane and the Clinical Center of Montenegro in Podgorica, where waste is transported in carts to the Medical Waste Treatment Center Ekomedika DOO.

Taking into account the fact that medical waste is recognized as a serious problem in modern society, there is a need for managing this type of waste. This leads to hazard minimization on the one hand, while on the other hand new risks arise during each phase of waste management. Additional hazards occur from scavenging at waste disposal sites and during the manual sorting of hazardous waste from health-care facilities. These practices are common in many regions of the world, especially in low- and middle-income countries.

Epidemiological studies indicate that when a medical worker, or a cleaning lady handling waste, suffers a needle injury, there is a risk of $30 \%$ of hepatitis B infection, $1.8 \%$ of hepatitis C, and $0.3 \%$ of HIV infection. According to the WHO data from 2002, the results of the assessment carried out in 22 developing countries have shown that the number of health institutions that do not use the appropriate methods for waste disposal ranges from $1 / 5$ up to $2 / 3$ of the total number of institutions. Stab wounds most commonly lead to the transmission of viral blood infections, but in addition to these infections there is also a danger of spreading bacteria resistant to antibiotics [23, 24]. 


\section{Medical Waste Management}

On the other hand, burdening the environment with hazardous and non-hazardous medical waste is caused by contaminating soil, water and air with pollutants from this waste. As with health impact, environmental pollution can occur at any stage of medical waste management, especially during collection, transport, temporary storage, and final disposal. Depending on the method of medical waste treatment (Figure 3), certain environmental consequences will occur. Landfills can contaminate drinking water if they are not properly constructed. Incinerated materials containing chlorine can generate dioxins and furans, which are human carcinogens and have been associated with a range of adverse health effects. Incineration of heavy metals or materials with high metal content (in particular lead, mercury and cadmium) can lead to the spread of toxic metals in the environment. However, the biggest threat of medical waste to the environment is the inadequate care or neglect of medical waste problems in some countries.

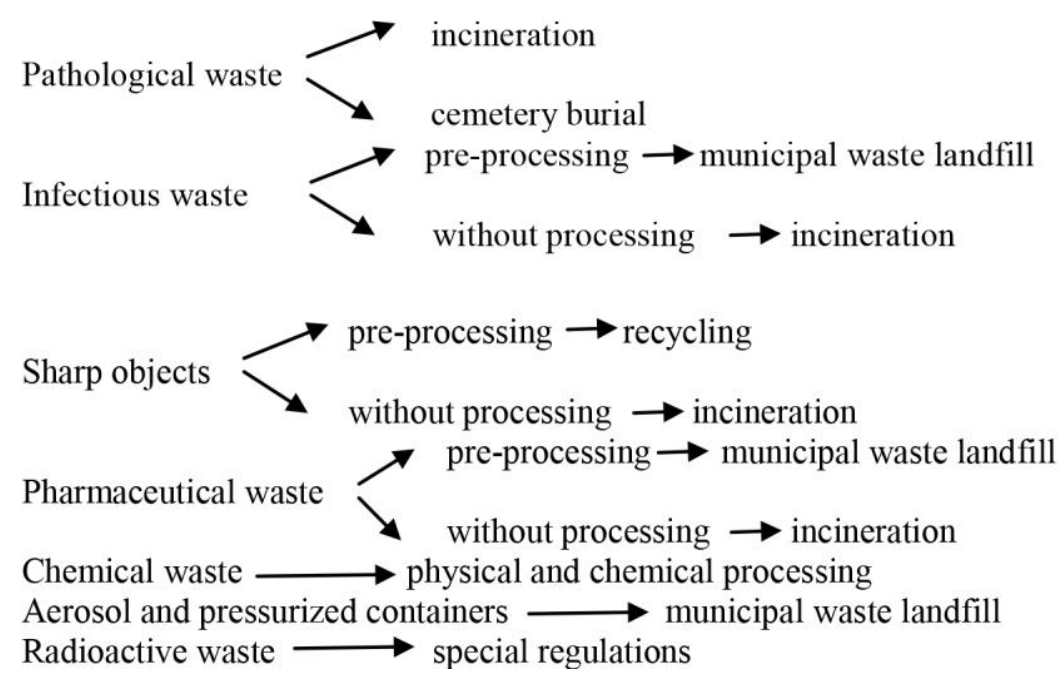

Fig. 3 A scheme with hazardous medical waste disposal possibilities [21]

Yet, the latest data is encouraging. In 2015, a joint WHO/UNICEF assessment found that just over half $(58 \%)$ of sampled facilities from 24 countries had adequate systems in place for the safe disposal of medical waste. In addition, in order to preserve human health and the environment, alternatives to incineration are now available, such as autoclaving, microwaving, steam treatment integrated with internal mixing, and chemical treatment.

The world is generating more and more waste and hospitals and health centers are no exception. Medical waste can be infectious, contain toxic chemicals and pose contamination risks to both people and the environment. If patients are to receive health care and recovery.

Therefore, a waste management working group must be set up by the hospital manager. The group must include the following members: the hospital project manager, the water and habitat engineer, the local waste manager, and members of the hospital staff, such as the hospital administrator, the head nurse, the head of radiology, the chief pharmacist and the head of laboratory. 
A draft waste management plan will then have to be drawn up using the data that has been collected. It must contain the following chapters, as shown in Table 6 and Figure 4 [25].

Table 6 Tools for drafting the waste management plan

\begin{tabular}{ll}
\hline Stages & Tools \\
\hline Inventory & $\begin{array}{l}\text { Quantification of waste; Checklist for describing the current } \\
\text { situation. }\end{array}$
\end{tabular}

Minimization / recycling Reducing the amount of waste at source; Purchasing policy and purchasing policy geared to minimizing risks; Product recycling; Stock management.

Sorting, collection, storage and transport

Waste sorting must always be the responsibility of the entity that produces it. It must be done as close as possible to the site where the waste is produced. Sorting principles; Coding recommendations (WHO - UNEP/SBC 2005); Vehicles and means of conveyance; On-site transport; Off-site transport; Crossborder transport.

Identification and Incineration; Chemical disinfection; Autoclaving; Needle evaluation of treatment / disposal options extraction or destruction; Shredders; Encapsulation; Disposal in a diagram of waste flows sanitary landfill or waste burial pit; Disposal of liquid waste in the

Protective measures sewage.

Personal protective equipment; Personal hygiene; Vaccination; Measures to be taken in the event of accidental exposure to blood; Emergency measures in the event of spills or contamination of surfaces; Emergency measures in the event of human contamination.

Training

Additional training for: care staff; staff handling waste, staff in charge of waste treatment plants or sanitary landfills, management and administrative staff.

Estimating costs

Medical waste management costs vary widely depending on the context, the amount of generated waste and the chosen treatment methods. A WHO estimate dating from 2003 shows that in a small health-care facility the cost per $\mathrm{kg}$ of waste incinerated in a SICIM-type single-chamber incinerator can range from $\$ 0.08 / \mathrm{kg}$ to $\$ 1.36 / \mathrm{kg}$.

Implementation strategy, The hospital project manager is responsible for implementing the audit and follow-up waste management plan. He can delegate certain tasks to the water and habitat engineer or the hospital administrator. The implementation of the plan includes the following steps: the approval and signing of the waste management plan; the allocation of resources; the assignation of tasks; the organization of training; regular audits and monitoring; on-going improvement of the waste management plan. 
The WHO handbook on Safe management of wastes from health-care activities known as The Blue Book is the result of extensive international consultations and cooperation with the aim of developing recommendations for medical waste management. The handbook provides comprehensive guidance on secure, efficient and environmentally safe methods for handling and disposing of waste from health-care activities in regular situations and emergencies. Based on these documents, the leading principles for medical waste management can be distinguished:

- Prevention of health risks related to the exposure of medical workers and the community to waste by promoting an environmentally-friendly policy of medical waste management;

- Supporting global efforts to reduce the amount of harmful emissions into the atmosphere;

- Supporting the Stockholm Convention on Persistent Organic Pollutants (POP);

- Supporting the Basel Convention on hazardous and other types of waste;

- Reducing exposure to toxic pollutants related to the combustion process by promoting appropriate incineration processes at high temperatures.

A diagram of waste flows should summarize the sorting procedures and treatment chains for the various types of waste. Figure 4 is an example of a diagram intended to support decision-making on the treatment methods to be used in the absence of appropriate regional infrastructures.

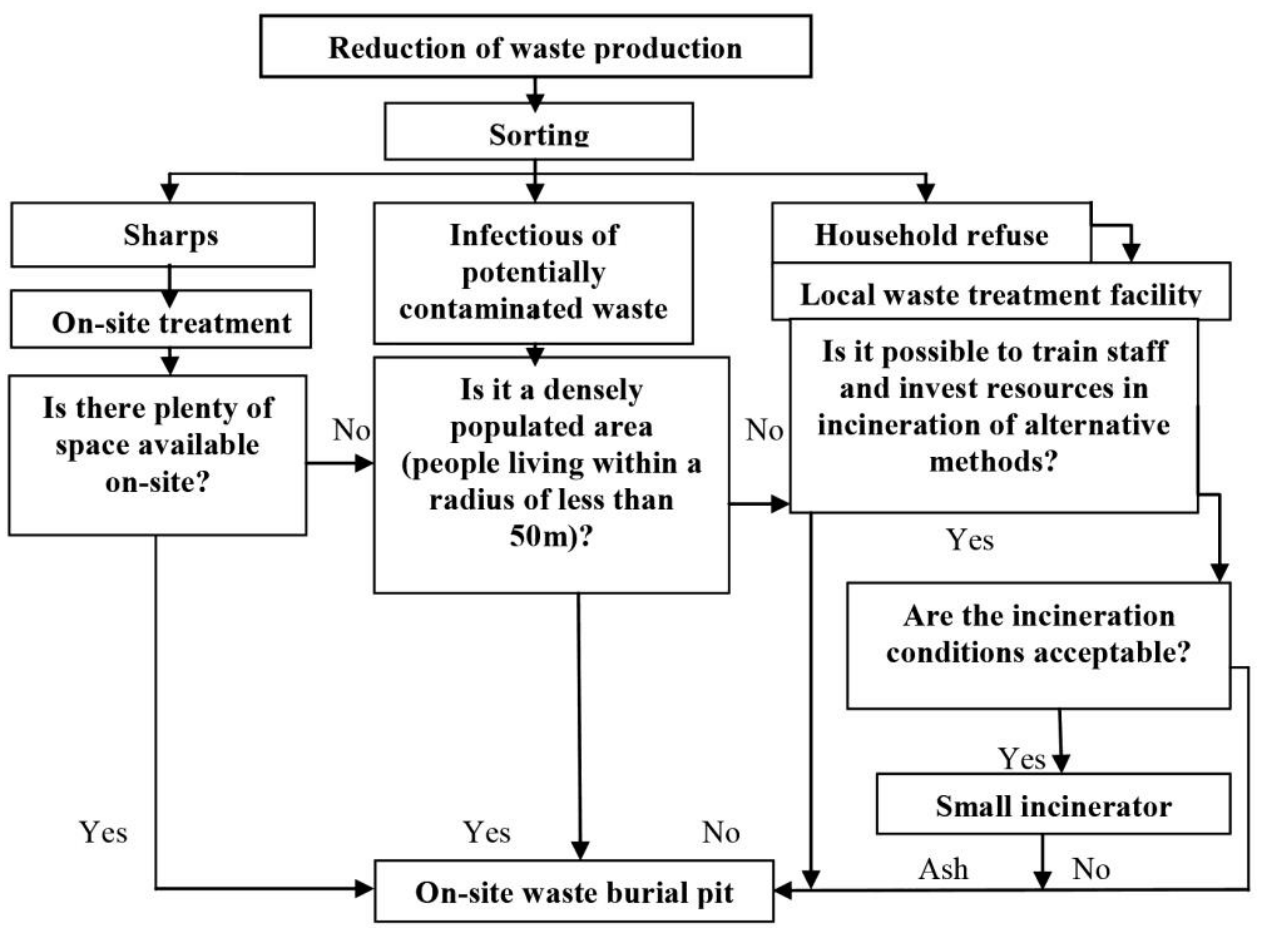

Fig. 4 Example of a diagram intended as a guide for deciding on the treatment/disposal methods to be used in the absence of appropriate regional infrastructures 


\section{CONCLUSIONS}

The primary goal of adequate and efficient management of hazardous medical waste in the narrow sense should be to protect and improve the health of individuals who are exposed to the impact, as well as to protect and preserve the environment in a wider sense.

The medical waste management system, as well as the environmental protection system and all the programs in this field are underdeveloped in Western Balkan countries and, therefore, they should be harmonized with the principles and standards of the EU and implemented in practice. In that sense, it is necessary to build permanent treatment plants, improve the equipment of health institutions by incorporating the appropriate handling equipment, as well as the equipment for occupational safety of people who are in contact with medical waste.

Acknowledgement: The paper is a part of the research conducted within the projects No. III43014, funded by the Serbian Ministry of Education, Science and Technological Development.

\section{REFERENCES}

1. Steen Windfeld E., Su-Ling Brooks M., Medical waste management - A review, Journal of Environmental Management, 163, 2015, pp. 98-108.

2. Waste management strategy for the 2010-2019 period, (Official Gazette of the Republic of Serbia, No. 29/10).

3. Law on Waste Management, ("Official Gazette of the Republic of Serbia ", No. 36/09, 88/10 and 14/16).

4. Law on Environmental Protection, ("Official Gazette of the Republic of Serbia", No. 135/2004, 36/2009, 36/2009 - other law, 72/2009 - other law, 43/2011 - decision US and 14 / 2016).

5. Law on the Confirmation of the Basel Convention on the Transboundary Movement of Hazardous Wastes and Their Disposal, ("Official Gazette of FRY - International Agreements", No. 2/99).

6. Rolebook on the management of medical waste, ("Official Gazette of the Republic of Serbia", No. 78/2010).

7. Rulebook on categories of waste together with lists, ("Official Gazette of the FBiH", No. 9/05).

8. Waste Management Plan 2008 - 2012 of Montenegro ("Official Gazette of Montenegro", No. 80/05).

9. Rulebook on the conditions, manner and procedure of medical waste treatment ("Official Gazette of Montenegro", No. 49/12).

10. Council Directive 75/442/EEC of 15 July 1975 on waste: Official Journal L 114/9, 27 April 1975.

11. Safe Management of Wastes from Health-care Activities. Geneva: World Health Organization, 2014.

12. Jovanović V., Analysis of healthcare waste management factors in the provision of healthcare services [dissertation]. Kragujevac: Faculty of Medical Sciences; 2017 (Serbian).

13. Makajic-Nikolic D., Petrovic N., Belic A., Rokvic M., Radakovic J., Tubic V., The fault tree analysis of infectious medical waste management. Journal of Cleaner Production, 113, 2016, pp. 365-373.

14. Chen J., Zhiyuan R, Yajing T., Kaixiang W., Application of best available technologies on medical wastes disposal/treatment in China (with case study). Procedia Environmental Sciences, 16, 2012, pp. 257-265.

15. Bokhoree C., Beeharry Y., Makoondlall-Chadee T., Doobah T., Soomary N., Assessment of Environmental and Health Risks Associated with the Management of Medical Waste in Mauritius. APCBEE Procedia, 9, 2014, pp. 36-41.

16. Djordjević A., Ristić G., Živković N., Todorović B., Hristov S., Milošević L., Respiratory diseases in preschool children in the city of Niš exposed to suspended particulates and carbon monoxide from ambient air. Vojnosanit Pregl, Vol. 73, No. 4, 2016, pp. 326-336.

17. Ristić G., Djordjević A., Hristov S., Umičević P., Petković A., Milošević L., Methodology for route optimization for solid waste collection and transportation in urban areas. Facta Universitatis, Series: Working and Living Environmental Protection, Vol. 12, No. 2, 2015, pp. 187-197.

18. Vranjanac Ž., Spasić D,. Economic and environmental effects of collection and primary recycling of packaging waste from hygiene and cleaning products in Serbia, Serbian Journal of Management, Vol. 12, No. 2, 2017, pp. 315-327. 
19. Medical waste Management. Geneva: International Committee of the Red Cross 19, 2011.

20. Jovanović D., Živković N., Routing problems in transportation of hazardous materials. Facta Universitatis, Series: Working and Living Environmental Protection, Vol. 7, No. 1, 2010, pp. 43-51.

21. Marinković N., Vitale K., Džakula A., Pavić T., Medical waste management in Croatia, Waste management, Vol. 28, No. 6, pp. 1049-1056.

22. Pranjić N., Agić Dž., Rizvić V., Medical waste management in northeastern Bosnia and Herzegovina, Study on medical waste. Tuzla: Centar for Ecology and Energy, 2011, pp. 80-85. (Bosnian)

23. Živković S., Takić Lj., Živković N., The improvement of environmental performances by applying ISO 14001 standard: A case study. Chemical Industry and Chemical Engineering Quarterly, Vol. 19, No.4, 2013, pp. 541-552.

24. Vasović D., Malenović Nikolić J., Janaćković G., Radosavljević J., Vukadinović A., Environmental Management Systems: contemporary trends and practices. Acta Technica Corviniensis-Bulletin of Engineering, Vol. 10, No. 1, 2017, pp. 145-147.

25. Preparation of national health care waste management plans in Sub-Saharan countries: Guidance manual/Secretariat of the Basel Convention and World Health Organization, 2005.

\section{ANALIZA USKLAĐENOSTI PROCESA UPRAVLJANJA MEDICINSKIM OTPADOM U ZEMLJAMA ZAPADNOG BALKANA I EU}

Globalno posmatrano, danas su sve intenzivnije negativne posledice uticaja medicinskog otpada na zdravlje ljudi i životnu sredinu. Te posledice manifestuju se infekcijama, povredama i bolestima sa jedne strane, dok sa druge prouzrokuju kontaminaciju zemljišta, vode $i$ vazduha zagađujućim supstancama iz medicinskog otpada. Cilj ovog rada je definisanje principa programa upravljanja medicinskim otpadom u okviru medicinskih ustanova. Analizom dosadašnjïh istraživanja o medicinskom otpadu u radu je dat sistematizovan prikaza definicije, klasifikacije i označavanja medicinskog otpada, kao i eko-toksikološkog rizika po životnu sredinu i zdravlje, čime je stvorena osnova za pregled strategija programa upravljanja ovom vrstom otpada. Na osnovu analize raspolažovih podataka o generisanom medicinskom otpadu na određenoj teritoriji mogu se primeniti mere adekvatnog upravljanja medicinskim otpadom u cilju otklanjanja ili minimizacije negativnih posledica ovog otpada na zdravlje ljudi i životnu sredinu. U okviru ovog rada korišćen je metod uporedne kvalitativne analize medicinskog otpada. Uz to, primenom analize potencijalnih metoda tretmana medicinskog otpada, ukazano je na značaj izbora strategija menađžmenta medicinskog otpada, što je sagledano iz vise perspektiva. Ključni rezultat ovog istraživanja jesu definisani principi za realizaciju programa menađžmenta medicinskim otpadom. Ovaj rad daje pregled alata za izradu plana upravljanja otpadom, kao i primer dijagrama koji je namenjen podršci donošenju odluka o metodama lečenja koje se koriste u odsustvu odgovarajuće regionalne infrastrukture.

Ključne reči: medicinski otpad, klasifikacija i označavanje, proces upravljanja 